\title{
Changes in Planktivory and Herbivory Regimes in a Shallow South American Lake (Lake Blanca Chica, Argentina) Over the Last 250 Years
}

\author{
David Carrozzo ${ }^{1}$, Simona Musazzi ${ }^{2}$, Andrea Lami ${ }^{2}$ (D) Francisco E. Córdoba ${ }^{3}(\mathbb{C})$ \\ and María de los Ángeles González Sagrario 4,*(D) \\ 1 Departamento de Biología, Universidad Nacional de Mar del Plata, J. B. Justo 2550, \\ Mar del Plata 7600, Argentina; davidrcarrozzo@gmail.com \\ 2 National Research Council (CNR),WaterResearchInstitute (IRSA), Largo Tonolli50, 28922 Verbania, Italia; \\ simona.musazzi@irsa.cnr.it (S.M.); andrea.lami@cnr.it (A.L.) \\ 3 Instituto de Ecorregiones Andinas (INECOA, CONICET-UNJu), Instituto de Geología y Minería, \\ Universidad Nacional de Jujuy, Av. Bolivia 1661, San Salvador de Jujuy Y4600GNE, Argentina; \\ francisco.e.cordoba@gmail.com \\ 4 Instituto de Investigaciones Marinas y Costeras (IIMYC), Facultad de Ciencias Exactas y Naturales, \\ Universidad Nacional de Mar del Plata, CONICET, J. B. Justo 2550, Mar del Plata 7600, Argentina \\ * Correspondence: gonsagra@gmail.com or gonsagra@mdp.edu.ar
}

Received: 24 December 2019; Accepted: 18 February 2020; Published: 22 February 2020

\begin{abstract}
Shallow lakes are vulnerable ecosystems impacted by human activities and climate change. The Cladocera occupy a central role in food webs and are an excellent paleoecological indicator of food web structure and trophic status. We conducted a paleolimnological study in Lake Blanca Chica (Argentina) to detect changes on the planktivory and herbivory regimes over the last 250 years. Generalized additive models were fitted to the time series of fish predation indicators (ephippial abundance and size, mucrone size, fish scales, and the planktivory index) and pheophorbide $a$ concentration. The cladoceran assemblage changed from littoral-benthic to pelagic species dominance and zooplankton switched from large-bodied (Daphnia) to small-bodied grazers (Bosmina) ca. 1900 due to increased predation. The shift in planktivory regime (ca. 1920-1930), indicated by fish scales and the planktivory index, as well as herbivory (ca. 1920-1950), was triggered by eutrophication. Changes in planktivory affected the size structure of Bosmina, reducing its body size. This study describes the baseline for the lake as well as the profound changes in the composition and size structure of the zooplankton community due to increased predation and the shift in the planktivory regime. These findings will provide a reference status for future management strategies of this ecosystem.
\end{abstract}

Keywords: Daphnia; Bosmina; pheophorbide $a$; fish predation; grazing; ephippia; cladocera sub-fossil remains

\section{Introduction}

Zooplankton play a pivotal role in aquatic ecosystems and global biogeochemical cycles. In fact, zooplankton act as a hinge in the aquatic food web because they exert a control role on phytoplankton through grazing (performed by herbivorous filter organisms such as cladocerans and rotifers) and are the food resource of higher trophic levels [1,2]. Zooplankton are highly sensitive to changes in aquatic ecosystems [3]. The effects of environmental disturbances can be detected through changes in species composition, abundance, and body size distribution. Grazing capacity on algae is directly related to the body size of organisms - the larger size, the greater grazing capacity [4]. Zooplankton are sensitive to the predation pressure exerted by fish (decreasing their body size) and macroinvertebrates 
(increasing their body size [5]). Jeppesen et al. [6] showed that the top-down control in shallow lakes is stronger due to the lower abundance of piscivorous relative to planktivorous and omnivorous fish. Cladocerans are an important component of the zooplankton and the chitinous structures of their exoskeleton (postabdomen, jaws, claws, antenna segments) and resistance eggs (ephippia) are an important, well-preserved, and taxonomically well-known autochthonous element of lake sediment. Due to their potential role as indicators of various environmental conditions, the study of subfossil remains of Cladocera has been very useful in identifying and inferring changes in trophic status, predation by fish and invertebrates, macrophyte coverage, as well as chemical and physical properties of lake water [7-9].

Shallow lakes are considered as an ecosystem model in which regime shift, that is, rapid and abrupt transition from one persistent regime to a different regime, can be studied [10]. Driving forces may be both stochastic events (for example, violent storms, massive fish death, and herbicide use) and gradual processes that slowly degrade system resilience (eutrophication or global warming) [10]. The fact that a shallow lake is in a clear or murky regime implies that it presents distinctive feedback mechanisms as well as community structure and functioning. Thus, lakes in a clear water regime colonized by submerged macrophytes with a moderate-low plant coverage, have good light penetration, low pelagic primary production, zooplankton of large body size, high diversity of invertebrates and fish, and a high ratio of piscivorous to planktivorous fish [11]. In these systems, the control of zooplankton over phytoplankton (top-downregulation) is favoured because the piscivorous fish reduce the pressure of predation on the Cladocera community, made up of species of large body size and greater capacity for grazing, and also macrophytes might offer refuge to large cladocerans against planktivores [12]. In contrast, in systems with a turbid regime, phytoplankton become dominant because these lakes have a high level of nutrients and there is weak regulation from above as zooplankton are composed of species with less grazing capacity. Furthermore, the piscivorous to planktivorous fish ratio is low [6]. The shift from a clear macrophyte-dominated regime to a turbid one implies a drastic change on the balance and the interaction between the benthic-littoral and pelagic environments, with impacts on the fluxes of organic matter and nutrients, as well as the composition of the different assemblages and communities [6]. For example, the loss of macrophytes implies a change in the composition of the Cladocera assemblage with a decrease in the proportion of littoral and benthic representatives.

The stability of the zooplankton community in shallow lakes is strongly linked to small changes in the surface sediment condition (e.g., bank of seeds and eggs, physical changes of sediment). These changes cannot be detected by short-term studies because they are visible over long-time scales (e.g., decades or centuries) but can potentially be revealed by high resolution paleolimnological studies [9].

Lake sediments are rich sources of paleoecological information derived from the functioning of the lake ecosystem as well as the surrounding watershed. Sedimentary archives have been used to address several issues such as acidification, eutrophication, and lake ontogeny [13,14]. Among the proxies preserved in the sediment, algal pigments have been shown to have the same periodicity as fish fluctuations, and the deposition rates of pigments derived from edible algae are increased by the grazing activity of large-bodied zooplankton [15]. Further, herbivory creates novel derivatives such as pheophorbide $a$ [16], and can increase the overall concentration of pigments in the remaining undigested material [16]. Thus, both accumulation rates and concentrations of sedimentary pigments are connected to the dynamic of zooplankton populations [17].

Size-selective fish predation has an impact on the zooplankton community structure, leading to the dominance of small-bodied species. As zooplankton remains are deposited in lake sediments in a direct and frequent way in proportion to zooplankton abundance, microfossils can be used to infer planktivorous predation pressure or even reconstruct fish stocks $[18,19]$. Several indicators of fish predation have been recognized as changes in ephippia size; the length of cladoceran mandibules, carapaces, or mucrones; or the planktivory index((Daphnia)/(Daphnia + Bosmina $))[11,20,21]$. For example, the size of Daphnia ephippium has been demonstrated to be directly related to the size of female-bearing 
eggs [22], whereas the length of the mucrone with the total length of the individual is the case for Bosmina huaronensis Delauchaux 1978 [23].

The main objective of this paper was to establish the occurrence of changes in the size of subfossil Cladocera remains and in the concentration of pheopigments in order to infer changes in the planktivory and herbivory pressure during the last 250 years in a shallow lake located on the Pampa Plain(Argentina).In this study, we identified changes in a herbivory biomarker on the size of B. huaronensis (mucrone) and the replacement of Daphnia species by a small cladoceran (Bosmina), indicating a change in two main ecological processes, grazing and planktivory over the last 250 years. The change in predation and grazing was mainly triggered by eutrophication. To evaluate changes in the planktivory and herbivory regimes, we determined the abundance of Daphnia and Bosmina species, the size of Daphnia species ephippia and Bosmina mucrone, the abundance of fish scales, and the concentration of pheophorbide $a$.

\section{Materials and Methods}

\subsection{Study Area}

Lake Blanca Chica ( $36^{\circ} 50^{\prime} 00.9^{\prime \prime}$ S; $60^{\circ} 28^{\prime} 00.9^{\prime \prime}$ W) (Figure 1) is located in the Pampa Plain area (Central Argentina, South America), which constitutes one of the largest areas of wetlands of South America [24]. The lake is a shallow (1-2 m), turbid (Secchi Disc depth: 0.2-0.3 m, chlorophyll $a$ concentration: $90-500 \mathrm{mg} \mathrm{m}^{-3}$ ), warm temperature, and a polymictic lake of alkaline water ( $\mathrm{pH}$ : 8-9.8). Currently, it is in eutrophic status (Total Phosphorus: 0.3-1.2 ppm), lacking submerged vegetation. The fish community is dominated by the planktivorous Odontesthes bonariensis (Valenciennes, 1835) in open waters and by the small fish Cheirodon interruptus (Jenyns, 1842) in the littoral zone. The zooplankton are composed of small-medium sized Cladocera, Rotifera, and Copepoda species [25].

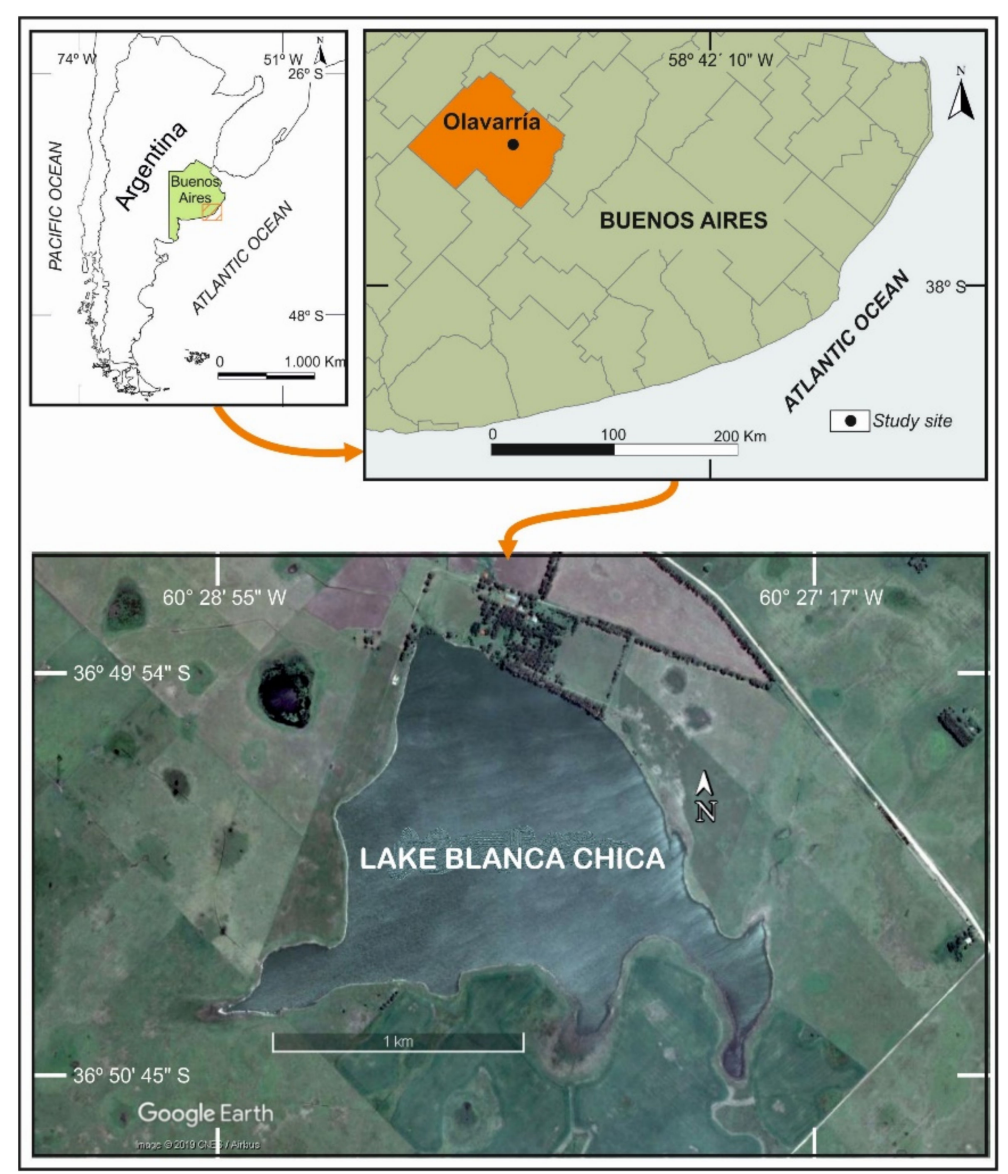

Figure 1. Location of Lake Blanca Chica in the the Argentinean Pampa Plain, South America. 


\subsection{Core Chronology and Paleolimnological Analyses}

A core of $60 \mathrm{~cm}$ was collected at the deepest part of the lake using a vibracorer on October 2015. Sub-sampling (every $1 \mathrm{~cm}$ interval) was carried out on the entire core. Results described in this study correspond to the top $30 \mathrm{~cm}$ of the core. Below this level, no pigments or ephippia were detected. The age-depth model was developed applying the constant flux/constant sedimentation (CFCS) model to the radionuclide activities of ${ }^{137} \mathrm{Cs},{ }^{210} \mathrm{~Pb}$, and ${ }^{226} \mathrm{Ra}$ (detected at the Radiochronology Laboratory of the Laval University, Canada). Three known chronomarkers were used to constrain the ${ }^{210} \mathrm{~Pb}$ model: the ${ }^{137} \mathrm{Cs}$ maximum peak at 6-7 cm as a time marker of A.D. 1964/1965; the first occurrence of Eucalyptus pollen (exotic tree)in the sedimentary record as a result of an extensive forestation since 1880 in Argentina; and a lithology change corresponding to an extreme regional dry pulse registered across the Pampean Plain at the end of the Little Ice Age (estimated to be A.D. $1775 \pm 10$ years) and recognized in other lakes, for instance, Mar Chiquita, Melincué [26,27]. For further details on the age-depth model, see [28].

Herbivory was inferred in determining the concentration of the pheophorbide $a$ as it represents a grazer biomarker of invertebrate herbivory [20]. This pigment was extracted with $5 \mathrm{ml}$ of a 90:10 acetone/MilliQwater solution overnight in the dark at $4{ }^{\circ} \mathrm{C}$, after flushing with nitrogen from around $1 \mathrm{~g}$ of wet sediment. Then, sediments were centrifuged at $3000 \mathrm{rpm}$ for 10 minutes before detection using high pressure liquid chromatography with an Ultimate 3000 system (Thermo Scientific, Waltham). The elution program and the methodology for pigment identification and quantification followed previous protocols [29].

Changes in the planktivory regime were inferred considering several indicators of fish predation: the abundance and size of Daphnia ephippia, the relative abundance and mucrone size of Bosmina, and the planktivory index((Daphnia)/(Daphnia + Bosmina) $)$ [11,21]. This index was calculated considering the relative contribution of ephippia from Daphnia spinulata Birabén 1917, Daphnia obtusa Kurz 1875, and B. huaronensis, as chitinous remains from Daphnia species were very scarce or not found in the sedimentary record. Values of the planktivory index closeto 1 indicate a low planktivorous pressure, but when the ratio decreases it represents a higher fish predation pressure. Chitinous remains, ephippia, and fish scales were retained through washing $2-8 \mathrm{~cm}^{3}$ of sediment gently through a $50 \mu \mathrm{m}$ sieve. Ephippia and fish scales were identified and were counted under a stereomicroscope at 10-40× magnification, whereas Bosmina remains were enumerated at 100-200xmagnification using a Zeiss Primo Star microscope. Bosmina remains were analysed on approximately a quarter of the sample after heating $\left(70-80^{\circ} \mathrm{C}\right)$ in $10 \% \mathrm{KOH}$, a deflocculating agent, for $45 \mathrm{~min}$ [30]. The length of the mucrone was considered as the distance from its base to its extreme, and the length of ephippia as the dorsal length, excluding anterior and posterior appendages. A total of 576 ephippia from D. spinulata, 324 from D. obtusa, 754 from Moina sp., and 1078 mucrones of B. Huaronensis were measured. At least 10 ephippia of each Daphnia species, 30 of Moina, and 30-50 mucrones of Bosmina were measured to calculate the mean size per stratigraphic level. The contribution of cladoceran species to the ephippia assemblage was expressed as weighted relative abundance [19], that is, ephippial relative abundance was weighted by that sample's total ephippial abundance. Several keys were used for taxonomic identification $[23,31-33]$.

\subsection{Data Analyses}

The time series of the different biological indicators was modelled using generalized additive models (GAMs) [34]. In all the cases, fitted GAMs were estimated using maximum likelihood-based smoothness selection procedures, in particular the restricted maximum likelihood (REML). A continuous time first-order autoregressive process (CAR(1)) was chosen to account for the correlation between residuals [35]. To identify periods of transition, we estimated simultaneous confidence intervals from the posterior distribution of the model (under an empirical Bayesian formulation), and the first derivative of the fitted trend [35]. Periods of significant change are identified as those time points where the simultaneous confidence interval on the first derivative bounded away from zero [35]. 
The estimation of the models and derivatives were performed using the mgcv and gratia packages. In the case of the size of ephippia or mucrones, GAMs were fitted to the time series of the mean size for each indicator. Fish scales abundance and chitinous remains of B. huaronensis data were provided by González Sagrarioand co-workers [28].

To summarize changes in the ephippial assemblage, correspondence analysis was performed (package vegan) [36] and the number of axes that best explained data variance were selected according to the Kaiser-Guttman criterion and the broken stick model [37]. For further details, see Figure S1.

All analyses were performed using $\mathrm{R}$ version 3.5.1 [38].

\section{Results}

\subsection{Herbivory Biomarker}

The fitted GAM to the time series of pheophorbide $a$ concentration explained a high percentage of data deviance and showed an increasing trend since ca. 1930. In particular, two increasing transitional periods occurred: ca. 1931-1949 and ca. 1991-2009 (Figure 2; Table 1), which indicate an increase in the total herbivory in the system.

(a)

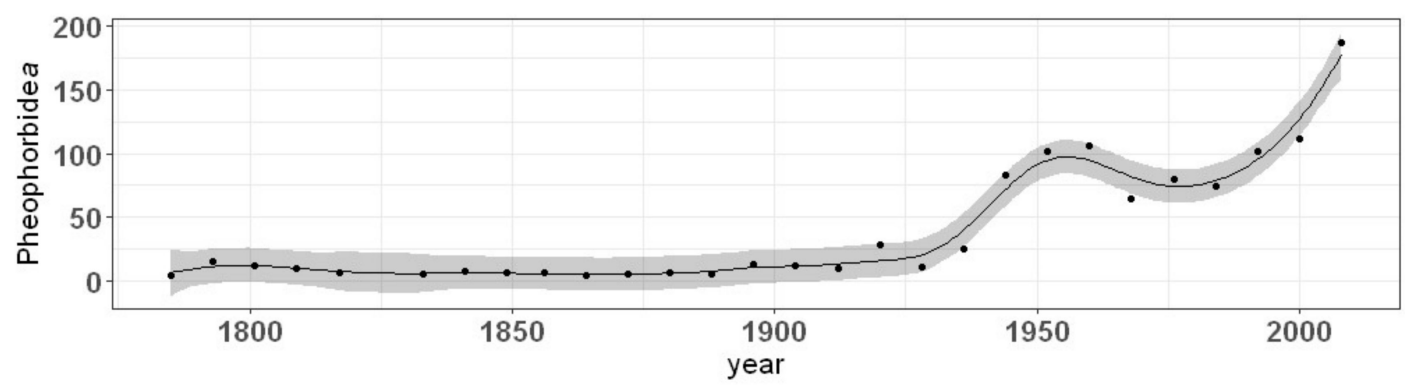

(b)

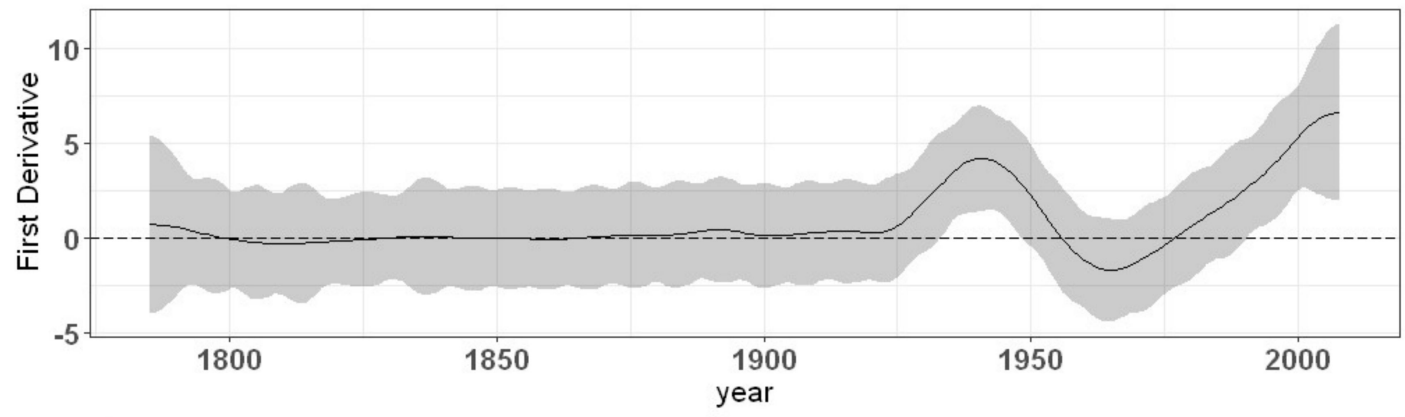

(c)

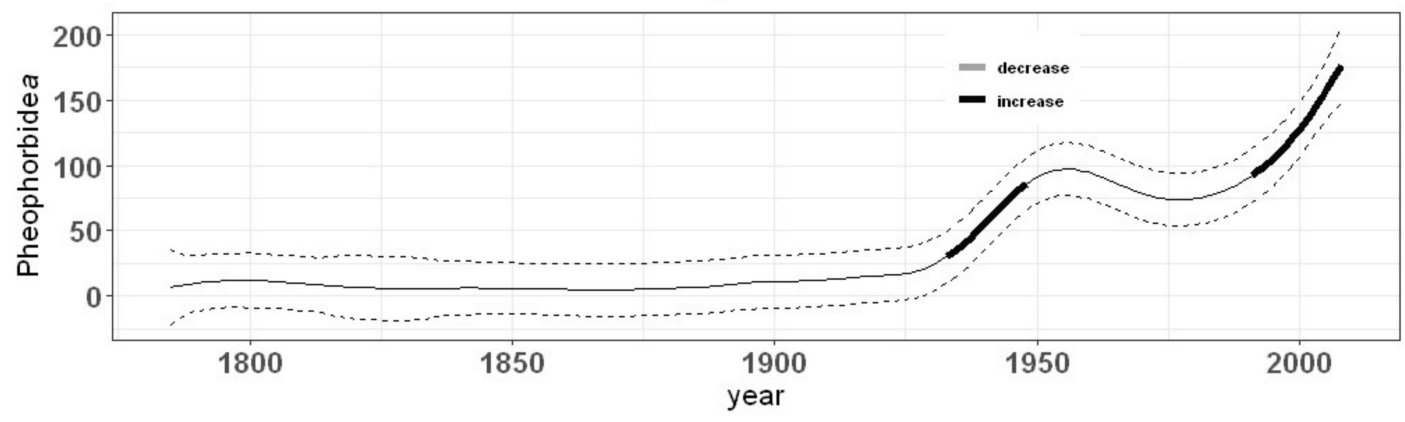

Figure 2. Generalized additive model (GAM) fitted to the time series of pheophorbide $a$ (expressed as $\eta$ Molesg $\mathrm{OM}^{-1}$ )in the sedimentary archive of Lake Blanca Chica. (a) Observed values, GAM-based trend fitted and its simultaneous interval; (b) estimated first derivative of the GAM-fitted trend and the 95\% simultaneous interval; (c) period of transition. 


\subsection{Ephippial Assemblage}

This study represents the first record of the ephippia of Daphnia spinulata, Daphnia obtusa, Bosmina Leiderobosmina huaronensis, Moina sp. Baird 1850, Ceriodaphnia sp. Dana 1853, Leydigia louisi Jenkin 1934cf, Pleuroxus sp. Baird1843, and Chydorus sphaericus (O. F: Müller 1776) group for the shallow lakes from the Pampa Plain. The weighted relative abundance of each species and the trend detected along the sedimentary record of Lake Blanca Chica can be found in Figures S1 and S2. Additionally, a decrease in the total sum of ephippia occurred after ca. 1915-1920, mostly represented by the loss of littoral species (Figures S1 and S3).

\subsection{Fish Predation Indicators}

The ephippia relative abundance and mean size of Daphnia species showed contrasting patterns. The effect of the smooth term for ephippia abundance and mean size was significant in all cases, and the fitted GAMs explained 25-38\% of time series deviance (Table 1). D. spinulata showed an increasing trend in the mean size of the ephippium along the entire time series. In contrast, the relative abundance of ephippia in the sedimentary record showed an increasing trend since ca. 1785-1815 until ca. 1900, and after that a decreasing trend, diminishing its relative contribution to the lake zooplankton towards the present time (Figures 3 and 4). Similarly, D. obtusa showed an increase in ephippia mean size ca.1950-1995 and its contribution to the ephippial assemblage decreased since ca. 1900 (Figures 3 and 5). No trend for Moina ephippia contribution or mean size was detected (Table 1). Indeed, both variables showed a high inter-decadal/inter-annual variation (Figure 3 and Figure S1).

The fitted GAM to B. huaronensis relative abundance (chitinous remains) explained a high percent of the data deviance of the time series (81.7\%) (Table 1). The first derivative of the fitted trend and its simultaneous interval showed an increase in Bosmina contribution ca. 1850-1880; after which no further change occurred (Figure 6). In contrast, a decrease in its size occurred ca. 1915-1935, stabilizing in a smaller size after 1940 (Figures 3 and 6; Table 1). For descriptive statistics on mucrone size, see Table S1.

Table 1. Results from generalized additive models (GAMs) fitted to the temporal series of the different proxies from the sedimentary record of Lake Blanca Chica. The estimated degrees of freedom (edf), $F$-statistic (Gaussian distributions) or chi-statistic (scaled or gamma distributions, values denoted by ${ }^{*}$ ), and $p$-values of the smooth term and the percent (\%) of the deviance explained by the fitted model are shown. The significance level was set at $p<0.05$; ns: non-significant results. All the fitted models were estimated using continuous time first-order autoregressive process (CAR(1)) and restricted maximum likelihood (REML)smoothness selection.

\begin{tabular}{ccccccc}
\hline Indicator & Species & $\%$ & $\boldsymbol{r}^{2}$ & $\boldsymbol{p}$-Value & Edf & F or Chi \\
\hline Ephippia weighted & D. spinulata & 25.2 & 0.205 & 0.01 & 0.870 & 3.362 \\
Abundance (\%) & D. obtusa & 25.8 & 0.213 & 0.00918 & 1.532 & $7.294^{*}$ \\
& Moina sp. & 9.63 & 0.0645 & Ns & 0.924 & 0.207 \\
Ephippia mean & D. spinulata & 35.4 & 0.329 & 0.000789 & 1 & 14.25 \\
Size & D. obtusa & 37.1 & 0.464 & $<1 \times 10^{-6}$ & 2.714 & $32.01 *$ \\
& Moina sp. & 8.01 & 0.0447 & Ns & 1 & 2.262 \\
Abundance (\%) & B. huaronensis & 81.7 & 0.778 & $9.12 \times 10^{-11}$ & 4.796 & 3.506 \\
Mucrone mean Length & B. huaronensis & 73.3 & 0.67 & $2.13 \times 10^{-5}$ & 5.118 & 8.71 \\
Pheophorbide $a$ & & 97.5 & 0.955 & $<2 \times 10^{-16}$ & 11.85 & 39.2 \\
Planktivory index & & 29.2 & 0.265 & 0.00106 & 1 & $10.71 *$ \\
Fish scales & & 64.4 & 0.547 & $2.6 \times 10^{-13}$ & 2.219 & 52.1 * \\
\hline
\end{tabular}




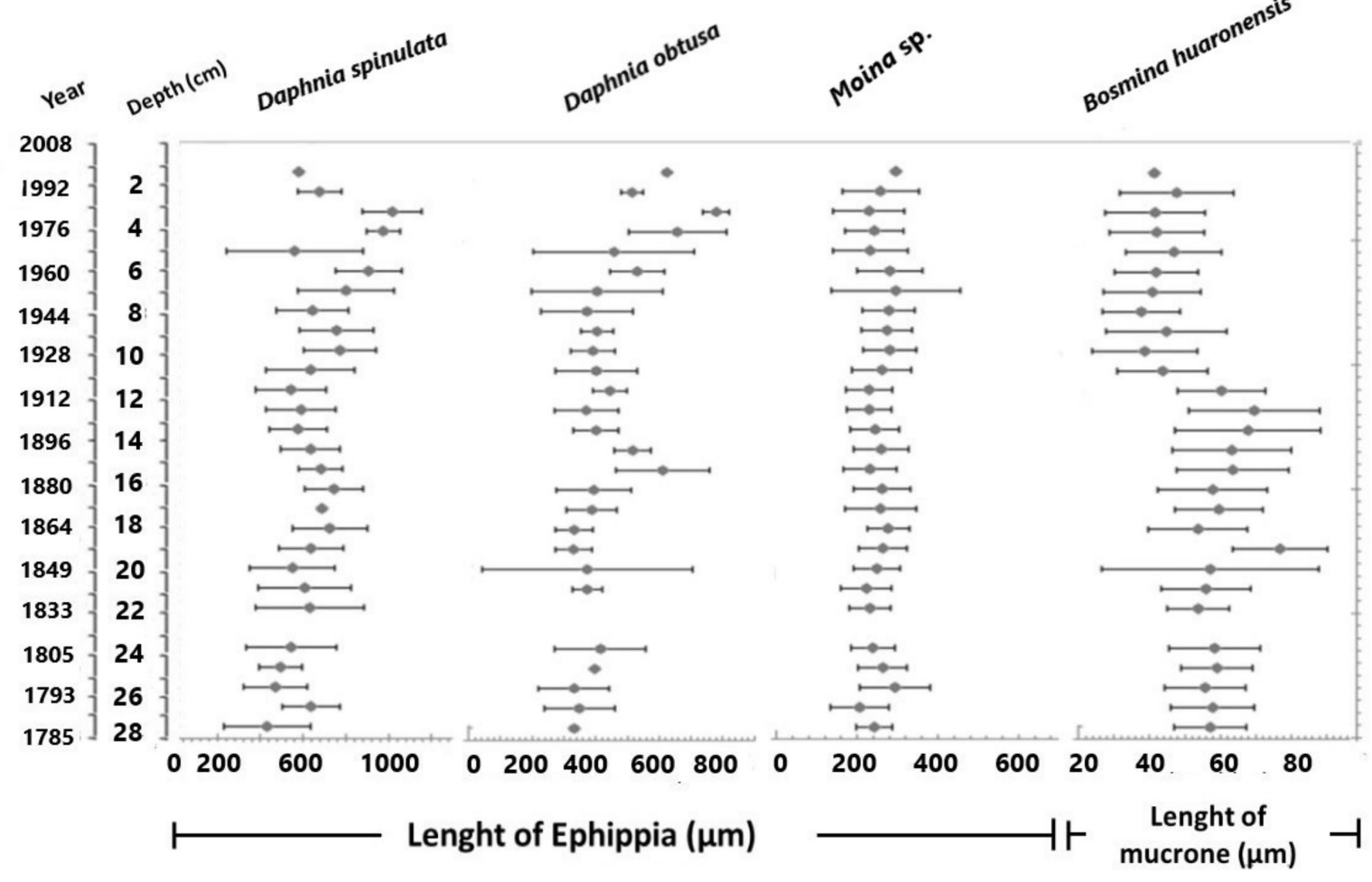

Figure 3. Size of the ephippia of Daphnia species and Moina sp. and the mucrone of Bosmina huaronensis in the sedimentary record of Lake Blanca Chica.

(a)
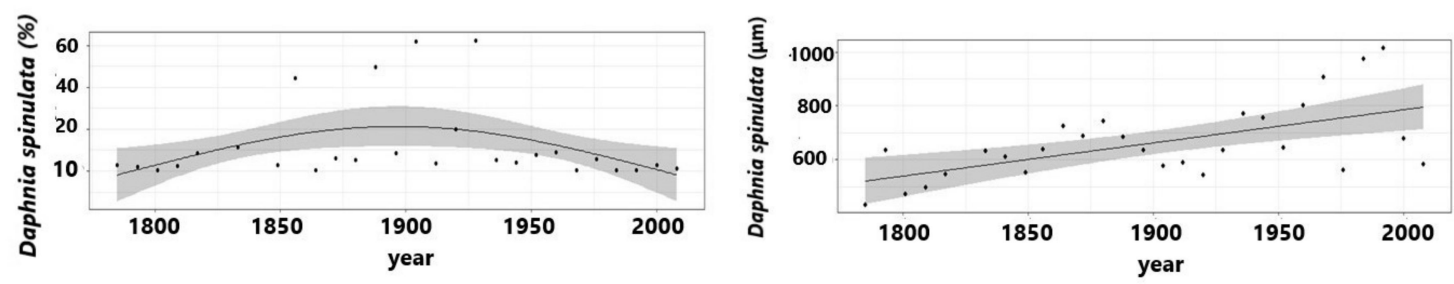

(b)
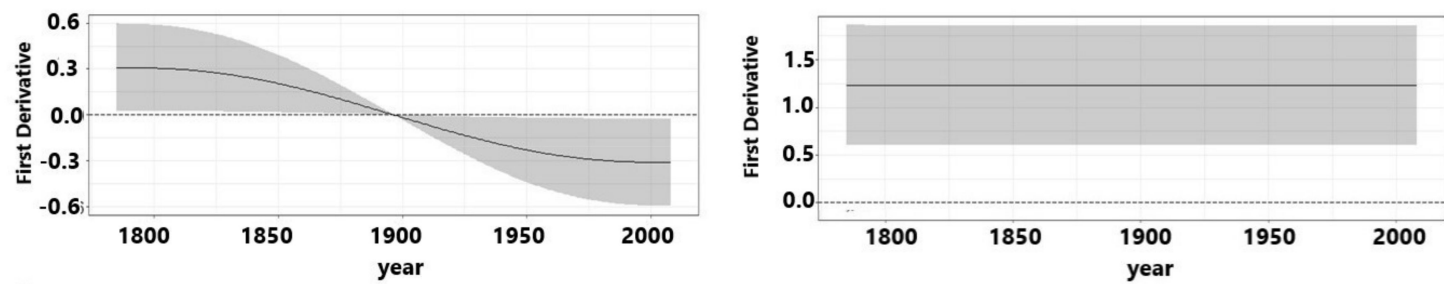

(c)
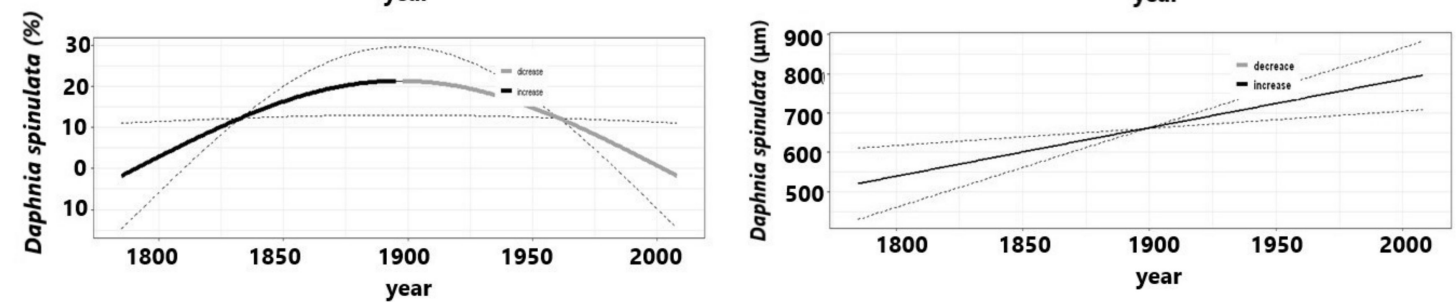

Figure 4. GAM fitted to the time series of Daphnia spinulata ephippia abundance (left pannel) and ephippia size (right pannel) in the sedimentary archive of Lake Blanca Chica. (a) Observed values, GAM-based trend fitted and its simultaneous interval; (b) estimated first derivative of the GAM fitted trend and the $95 \%$ simultaneous interval; (c) period of transition. 
(a)
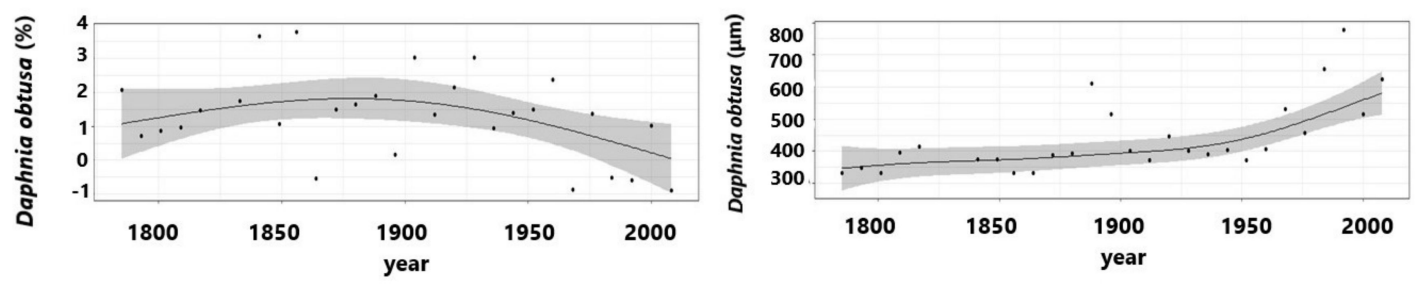

(b)
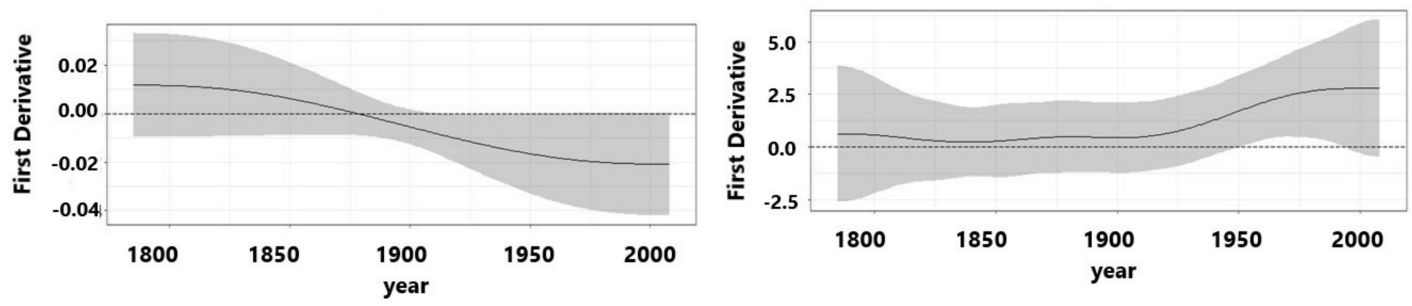

(c)
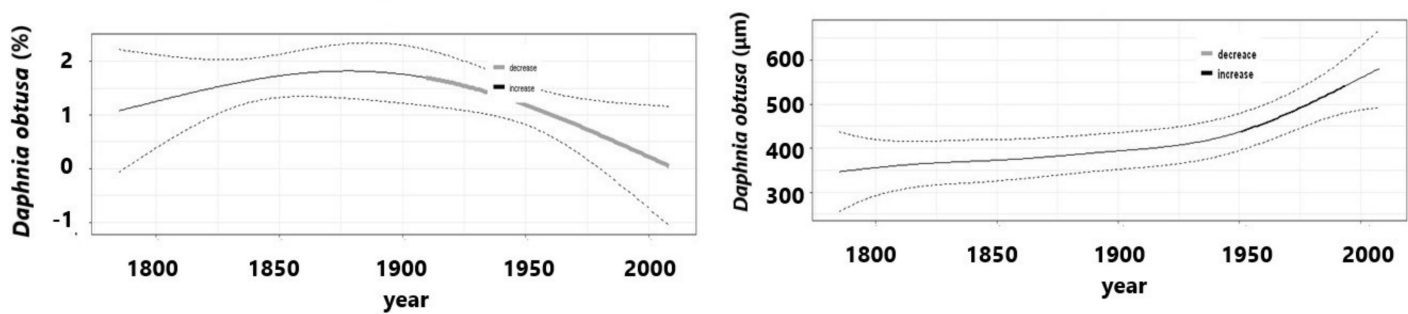

Figure 5. GAM fitted to the time series of Daphnia obtuse ephippia abundance (left pannel) and ephippia size (right pannel) in the sedimentary archive of Lake Blanca Chica. (a) Observed values, GAM-based trend fitted and its simultaneous interval; (b) estimated first derivative of the GAM fitted trend and the 95\% simultaneous interval; (c) period of transition.

(a)
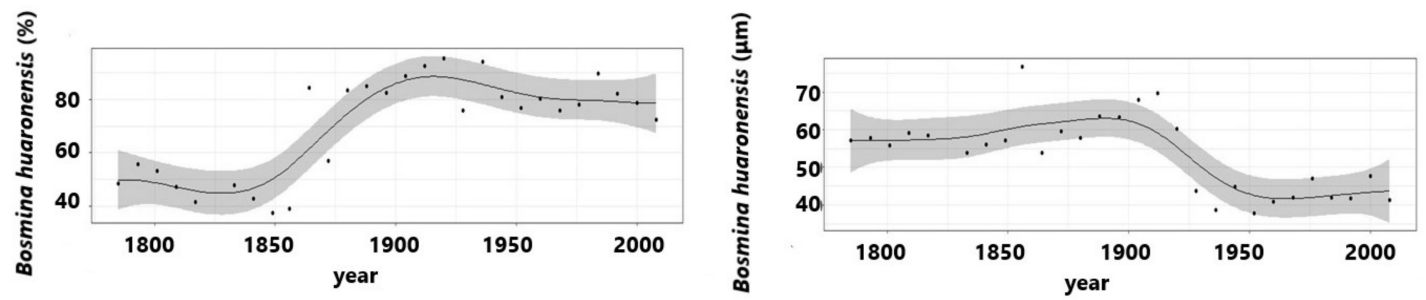

(b)
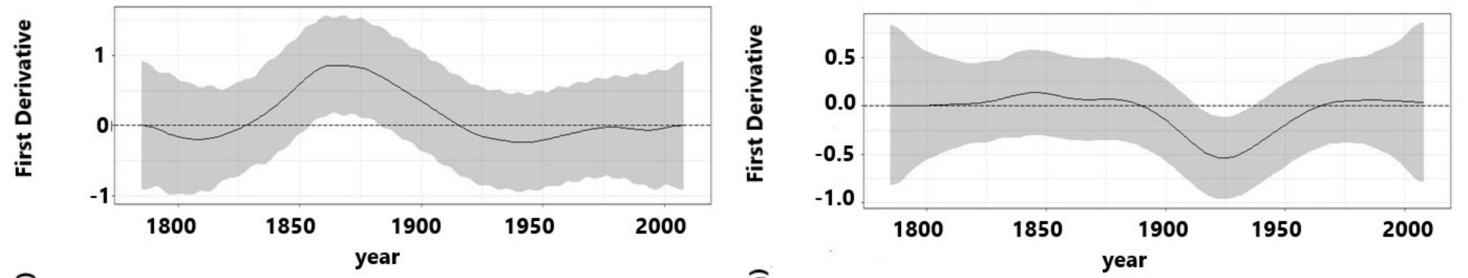

(c)
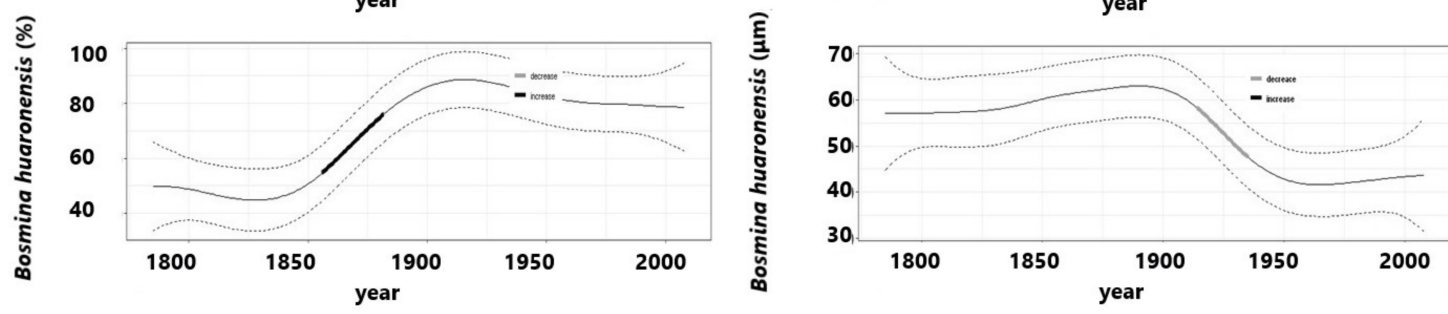

Figure 6. GAM fitted to the time series of Bosmina huaronensis abundance (chitinous remians) (left pannel) and mucrone size (right pannel)in the sedimentary archive of Lake Blanca Chica. (a) Observed values, GAM-based trend fitted and its simultaneous interval; (b) estimated first derivative of the GAM fitted trend and the $95 \%$ simultaneous interval; (c) period of transition. 
Fish scale abundance, an indicator of fish abundance, showed an increasing trend since ca.1930 to 2000 according to the first derivative of the fitted GAM. The model explained a high percentage of data deviance (64.4\%) (Table 1; Figure 7). In concordance, a decreasing trend in the planktivory index occurred along the time series (Table 1; Figure 8). The GAM fitted to the planktivory index explained $29.2 \%$ of the deviance, and although it showed a decreasing pattern, it can also be observed that most of the values lower than 0.5 occurred after 1900 (Figure 8).

(a)

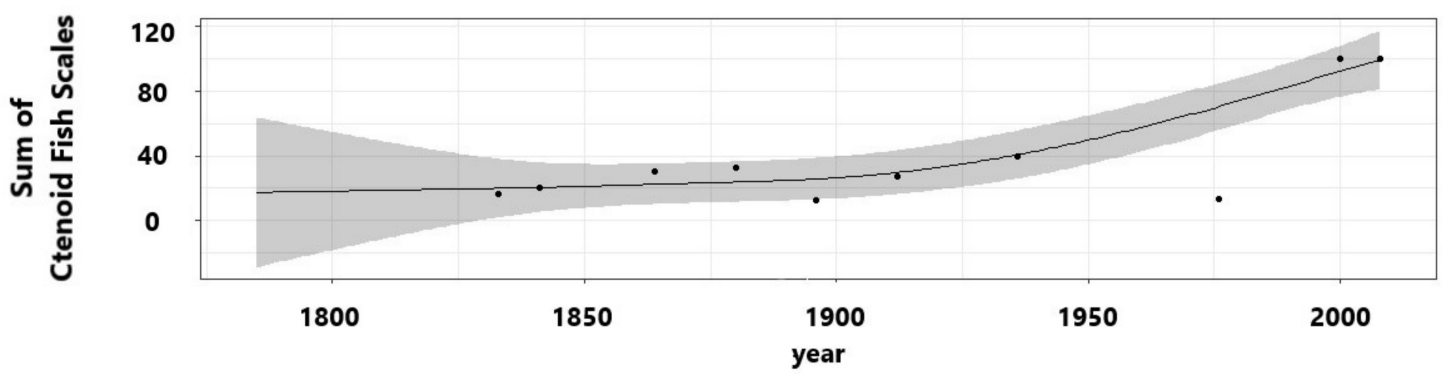

(b)

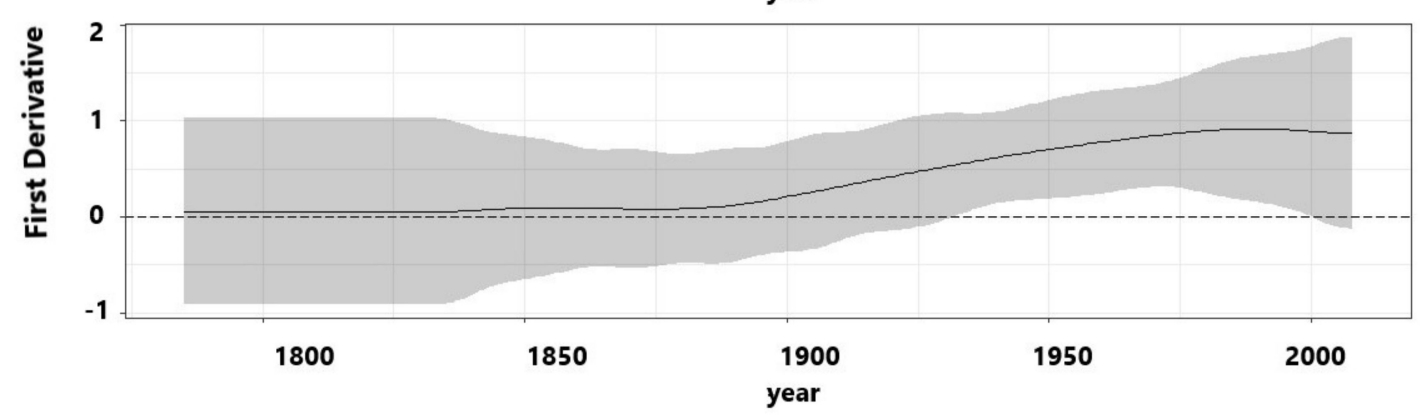

(c)

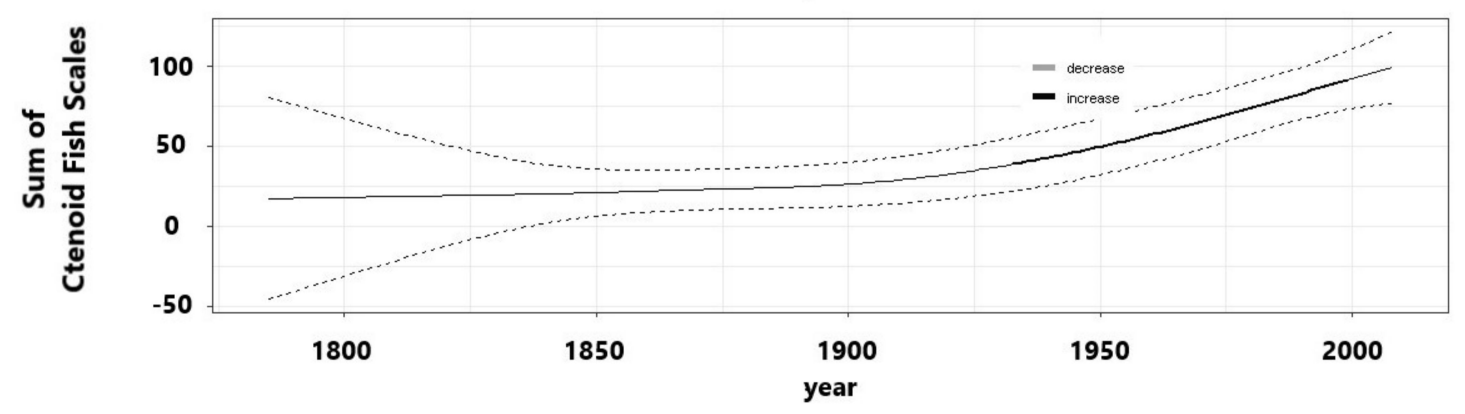

Figure 7. GAM fitted to the time series of fish scale abundance in the sedimentary archive of Lake Blanca Chica. (a) Observed values, GAM-based trend fitted and its simultaneous interval; (b) estimated first derivative of the GAM fitted trend and the $95 \%$ simultaneous interval; (c) period of transition. 
(a)

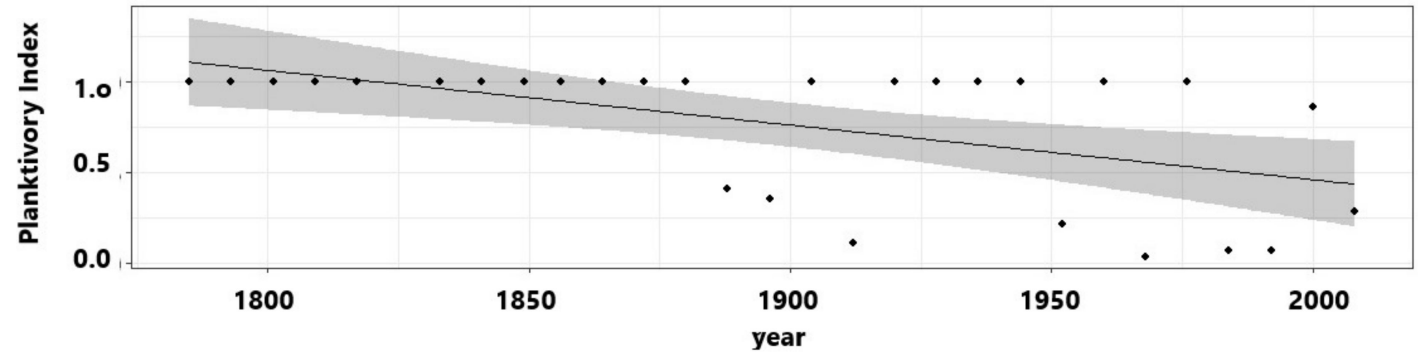

(b)

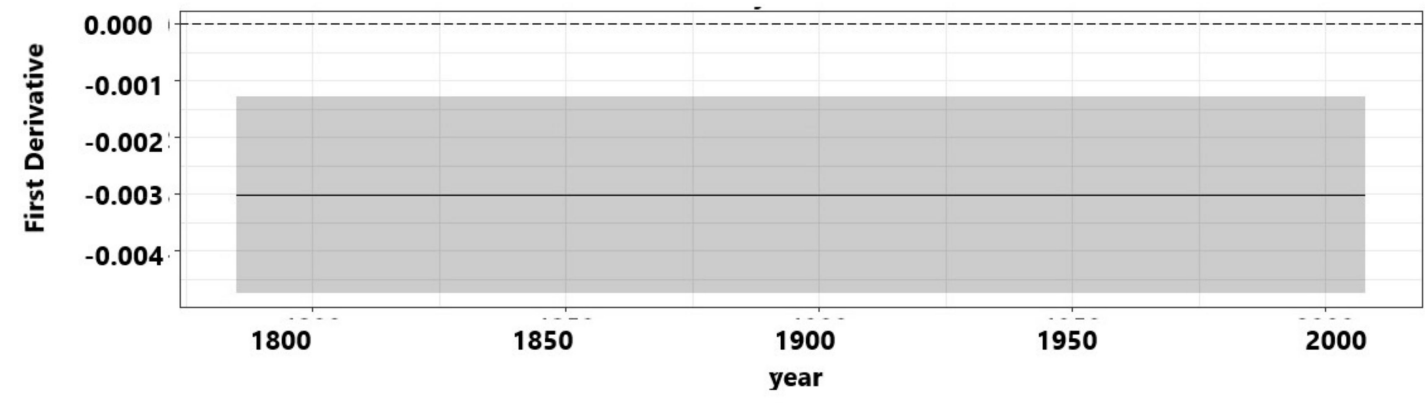

(c)

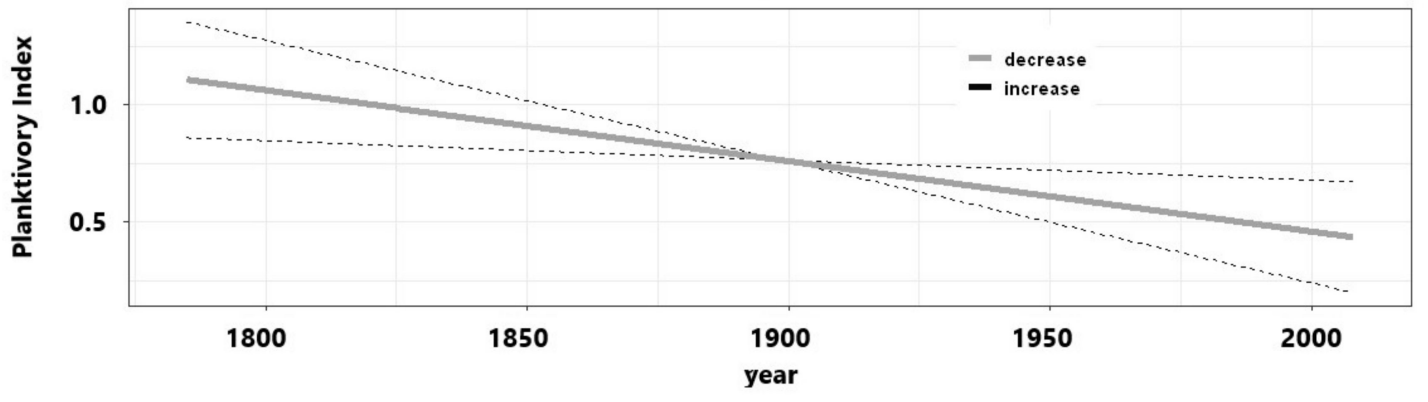

Figure 8. GAM fitted to the planktivory index (Daphnia/(Daphnia + Bosmina)) estimated from the ephippial assemblage in the sedimentary archive of Lake Blanca Chica. (a) Observed values, GAM-based trend fitted and its simultaneous interval; (b) estimated first derivative of the GAM fitted trend and the 95\% simultaneous interval; (c) period of transition.

\section{Discussion}

Predation and grazing are the principal processes that control community composition and size structure in lake ecosystems [6]. We found major changes in planktivory and herbivory in Lake Blanca Chica over the last 250 years. The alteration of zooplankton composition and size structure, the increase in the contribution of fish scales, and the decrease of the planktivory index are indicative of a shift in the planktivory regime. On the other hand, the increase of a biomarker of invertebrate grazing supports a change in the herbivory regime. Thus, this study shows a switch in the grazing and predation pressure and, as a consequence, in the fluxes of the pelagic food web.

Bosmina and Daphnia species showed opposite population dynamics in relation to their abundance prior to and post ca. 1900.The cladoceran assemblage changed its composition (ca. 1880-1900), shifting from being rich in littoral, benthic, and pelagic species (including Pleuroxus, Chydorus, Leydigia, Ceriodaphnia, Moina, B. huaronensis, D. spinulata, and D. obtusa) to being dominated by B. huaronensis. This fact is supported by the high contribution of chitinous remains $(\sim 80 \%)$ (Figure 6$)$ and the appearance of Bosmina ephippia in the lacustrine archive post ca. 1900 (Figure S1). Several mechanisms can explain the abrupt change that occurred in the zooplankton community. The switch in the chitinous remains and in the diatom assemblages in Lake Blanca Chica (ca. 1880-1900) has been associated with an increase of the lake water level that affected the physical structure of the lake [28]. This abrupt change was triggered by the increase in precipitation since ca. 1870/1880 [39] and involved a switch in the relationship between the littoral and pelagic habitat and the loss of the aquatic vegetation [28]. Pelagic cladocerans perform dial horizontal migrations to littoral areas during the daytime, finding 
refuge on the edge or inside submerged macrophyte stands to escape from planktivorous fish that occur in open water. However, neolimnological studies showed that the role of macrophyetesas refuge areas in subtropical temperate shallow lakes from the Southern Hemisphere differs from cold temperate shallow lakes from the Northern Hemisphere $[5,12,40]$. These studies were performed on eutrophic shallow lakes, and demonstrated that the lack of refuge provision in the southern lakes was due to the rich and abundant assemblage of predacious macroinvertebrates and small littoral fish that also seek refuge in macrophyte stands $[5,12,40]$. Despite this, the trophic status of Blanca Chica was not eutrophic before 1920-1930, according to a C/N relationship of around 25 [28]. Fish and macroinvertebrate abundance is directly correlated with primary production and nutrient level [6]. Thus, the abundance of small fish and predacious macroinvertebrates in the macrophyte stands must have been low given the $\mathrm{C} / \mathrm{N}$ ratio of $\sim 25$; therefore, aquatic vegetation could have provided refuge to zooplankton, counteracting planktivory. Indeed, D. spinulata was favoured until 1900, as shown by an increasing trend. The increase in fish predation, evidenced by low values of the planktivory index, and the loss of the vegetation from the system (ca. 1880-1900) might have exposed zooplankton to a higher predation risk, making large-bodied species such as $D$. spinulata and D. obtusa more vulnerable to fish predation than small-bodied species such as Bosmina. Altogether, the change in the physical structure of the lake and the predation increase might have facilitated the decline of Daphnia species, and would have probably favoured Bosmina dominance, releasing it from Daphnia competition in addition to the benefit of its smaller size. The top-down regulation and the competition release are the most plausible mechanisms that led to Bosmina dominance because no enhancement of primary production (bottom-up regulation) was recorded for the period of the shift. The same mechanisms have been proposed to explain the shift from Daphnia to Bosmina in other lakes [41].

The mucrone (Bosmina) and ephippial (Daphnia) size decreases serve as independent indicators of planktivorous fish predation $[3,21,42,43]$. A shift in the planktivory regime occurred in the lake ca. 1930, indicated by the increase of fish scales since 1930 until present day and by the decreasing trend of the planktivory index (Figures 7 and 8). In this case, the higher top-down control on the zooplankton impacted the size composition of Bosmina, which showed a reduction in its body size during 1915-1930 (Figures 3 and 6). An important consideration in paleolimnological studies about Bosmina morphology is to obtain a statistically valid estimate of size structure [43]. A minimum sample size of 35 remains per stratigraphic level was determined as necessary to detect a statistically significant variation in size [44]. In our study, we measured between 30-60 remains per sample of sediment; thus, the mucrone size reduction results detected are valid, accurate, and act as an independent indicator in supporting the shift in the planktivory regime and the enhanced top-down control. The main driver of this shift was the eutrophication process that the lake underwent between 1920 and 1990 [28]. Our findings are in agreement with several studies that have recorded changes in the zooplankton composition and size structure as a result of an eutrophication process, leading to an increase of pelagic taxa, a replacement of large-bodied Daphnia by small-bodied Bosmina or Ceriodaphnia, and/or changes in the body size of pelagic taxa in different types of lakes (deep and shallow) $[41,45,46]$.

Planktivorous fish select the larger species or individuals; thus, zooplankton display different strategies such as the reduction of its body size to counteract fish predation [4]. The increase in Daphnia body size or the lack of a specific trend in Moina sp. constitute the opposite expected patterns under an increasing fish predation scenario; then, it cannot be associated to planktivory. Even though, it can be explained by other mechanisms. D. spinulata increased its size over the entire time series whereas D. obtusa did so since ca.1950, that is, during the eutrophication phase. Jeppesen et al. [21] found that for a given CPUE (fish catch per unit of effort), Daphnia ephippia size apparently increased with total phosphorous (P). All Daphnia species are sensitive to food quality, requiring algae rich in phosphorous (P) content [47], and small Daphnia species, such as D. spinulata or D. obtusa, are favoured in high P lakes as they are less adversely affected by cyanobacteria filaments than large Daphnia species [48]. Therefore, a possible explanation is that the ephippiasize is bottom-up regulated, as no invertebrate predator occurred in this lake (such as Chaoborus or other cladocerans) and thus an increase in ephippia 
size could not be induced. In the case of Moina, a summer species in shallow Pampean lakes, the high inter-annual/decadal variation in abundance and size could be associated with a low selection pressure and/or a mismatch with young of the year fish during this period.

Considering the different responses found in this study and combining Bosmina and Daphnia abundance and size trends, it is clear that they cannot be explained by a specific type of control. The explanation most likely lies in the interaction of an increase in nutrient concentration in the system (rendering a higher zooplankton production and higher Daphnia size) and a top-down control by planktivorous fish (impacting on the composition of the pelagic assemblage and the size of the dominant pelagic cladoceran, Bosmina).

The pheophorbide $a$, a grazer biomarker of invertebrate herbivory, has increased over two periods in Lake Blanca Chica: ca. 1930-1950 and 1990 until the present day. The increasing trend and the detected transitions also coincide with the eutrophication process in the lake and with the increase of the total sum of chitinous remains (represented by pelagic, benthic, and littoral species) [28], implying an increase of the overall grazing pressure in the system. The production of this pigment results from a higher food availability (bottom-up regulation) and a top-down control of herbivorous invertebrates, even when in the cladoceran assemblage the large-bodied species were replaced by small-bodied species with less grazing capacity. It seems that the higher zooplankton production counteracts, at least in part, the loss of species with higher clearance rates.

In this study, we found shifts in the herbivory and the planktivory regime in Lake Blanca Chica over the last 250 years, with impacts on different trophic levels and also on different attributes of populations and communities. The shift in herbivory implied a higher control over lake primary producers and, probably, a major flux of pelagic, and also littoral/benthic, carbon to higher trophic levels. Changes in predation pressure led to compositional changes in the zooplankton, with the replacement of large-bodied Daphnia by small-bodied Bosmina, and also to a reduction of body size in the latter. Shifts in predation pressure were first (ca. 1880-1900) related to a natural driver (hydrology) and then reinforced by eutrophication (ca. 1920-1930). The first driver induced an increase in predation risk due to the loss of refuge in littoral areas and the second one by an increment in the lake fish stock. Thus, we demonstrated that human activities and climate change affect relevant lake processes such as grazing and predation, inducing profound impacts on the function, structure, as well as in fluxes across lake food webs. In addition, our findings represent the first record of the ephippial assemblage for Pampean shallow lakes, showing the baseline condition for these lakes. These results should be taken into consideration when managing restoration activities are carried out in these degraded shallow lakes. Lastly, we emphasize and agree with previous results [49], pointing out that cladocerans are a strong candidate for the single best indicator in paleoecological studies related to the alteration in food web structure and changes in trophic status in shallow lakes.

Supplementary Materials: The following are available online at http://www.mdpi.com/2073-4441/12/2/597/s1: Figure S1: Ephippial stratigraphy of Lake Blanca Chica, including the scores from the first and second axes of correspondence analysis. Figure S2: GAM fitted to the time series of scores of the second axis (CA2) of the correspondence analysis estimated for the ephippial assemblage in the sedimentary record of Lake Blanca Chica. Figure S3: GAM fitted to the time series of ephippia (total sum) recorded in the sedimentary archive of Lake Blanca Chica. Table S1: Descriptive statistics for the size of the ephippia $(\mu \mathrm{m})$ of Daphnia spinulata, Daphnia obtuse, and Moina sp., as well as the mucrone of Bosmina huaronensis $(\mu \mathrm{m})$.

Author Contributions: Conceptualization, M.d.l.Á.G.S.; methodology, D.C., F.E.C., and M.d.l.Á.G.S.; validation, M.d.1.Á.G.S.; formal analysis, D.C.; investigation, D.C., S.M., A.L., F.E.C., and M.d.l.Á.G.S.; resources, S.M., A.L., and M.d.l.Ã.G.S.; writing—original draft preparation, S.M., A.L., and M.d.1.Á.G.S.; writing—review and editing, D.C., S.M., A.L., F.E.C., and M.d.l.Á.G.S.; visualization, D.C.; supervision, M.d.l.Á.G.S.; project administration, A.L. and M.d.l.Á.G.S.; funding acquisition, A.L. and M.d.l.Á.G.S. All authors have read and agreed to the published version of the manuscript.

Funding: This research was supported by National Council of Scientific and Technical Research CONICET (grant: PIP 465/2013), National Research Council (CNR), Water Research Institute (IRSA), Bilateral Cooperation Project CONICET-CNR/2015 and Mar del Plata University (EXA775/2017). 
Acknowledgments: We thank A. Kotov for all the material that was shared to M.d.l.Ã.G.S., J.C. Paggi for his help with Cladocera identification, to the three anonymous reviewers that contributed with their comments to improve this manuscript, and to G. Free and R. Burks for the English style edition.

Conflicts of Interest: The authors declare no conflict of interest. The funders had no role in the design of the study; in the collection, analyses, or interpretation of data; in the writing of the manuscript; or in the decision to publish the results.

\section{References}

1. Dumont, H.J.; Van de Velde, I.; Dumont, S. The dry weight estimate of biomass in a selection of Cladocera, Copepoda and Rotifera from the plankton, periphyton and benthos of continental waters. Oecologia 1975, 19, 75-97. [CrossRef]

2. Sterner, R.W. Role of Zooplankton in Aquatic Ecosystems. In Encyclopedia of Inland Waters; Likens, G.E., Ed.; Academic Press: Oxford, UK, 2009; pp. 678-688.

3. Nevalainen, L.; Brown, M.; Manca, M. Sedimentary record of cladoceran functionality under eutrophication and re-oligotrophication in Lake Maggiore, Northern Italy. Water 2018, 10, 86. [CrossRef]

4. Brooks, J.; Dodson, S. Predation, body size, and composition of plankton. Science 1965, 150, 28-35. [CrossRef] [PubMed]

5. González Sagrario, M.A.; Balseiro, E. The role of macroinvertebrates and fish in regulating the provision by macrophytes of refugia for zooplankton in a warm temperate shallow lake. Freshw. Biol. 2010, 55, 2153-2166. [CrossRef]

6. Jeppesen, E.; Jensen, J.P.; Søndergaard, M.; Lauridsen, T.; Pedersen, L.J.; Jensen, L. Top-down control in freshwater lakes: The role of nutrient state, submerged macrophytes and water depth. Hydrobiologia 1997, 342, 151-164. [CrossRef]

7. Korosi, J.B.; Paterson, A.M.; DeSellas, A.M.; Smol, J.P. Linking mean body size of pelagic Cladocera to environmental variables in Precambrian Shield lakes: A paleolimnological approach. J. Limnol. 2008, 67, 22-34. [CrossRef]

8. Hann, B.J. Methods in Quaternary Ecology \#6. Cladocera. Geosci. Can. 1989, 16, 17-26.

9. DeSellas, A.M.; Paterson, A.M.; Sweetman, J.N.; Smol, J.P. Cladocera assemblages from the surface sediments of south-central Ontario (Canada) lakes and their relationships to measured environmental variables. Hydrobiologia 2008, 600, 105-119. [CrossRef]

10. Scheffer, M.; Jeppesen, E. Regime Shifts in Shallow Lakes. Ecosystems 2007, 10, 1-3. [CrossRef]

11. Jeppesen, E.; Leavitt, P.; De Meester, L.; Jensen, J.P. Functional ecology and palaeolimnology: Using cladoceran remains to reconstruct anthropogenic impact. Trends Ecol. Evol. 2001, 16, 191-198. [CrossRef]

12. Meerhoff, M.; Iglesias, C.; De Mello, F.T.; Clemente, J.M.; Jensen, E.; Lauridsen, T.L.; Jeppesen, E. Effects of habitat complexity on community structure and predator avoidance behaviour of littoral zooplankton in temperate versus subtropical shallow lakes. Freshw. Biol. 2007, 52, 1009-1021. [CrossRef]

13. Catalan, J.; Pla-Rabés, S.; Wolfe, A.P.; Smol, J.P.; Rühland, K.M.; Anderson, N.J.; Kopáček, J.; Stuchlík, E.; Schmidt, R.; Koinig, K.A.; et al. Global change revealed by palaeolimnological records from remote lakes: A review. J. Paleolimnol. 2013, 49, 513-535. [CrossRef]

14. Battarbee, R.W. Mountain lakes, pristine or polluted? Limnetica 2005, 24, 1-8.

15. Carpenter, S.R.; Leavitt, P.R. Temporal variation in a paleolimnological record arising from a trophic cascade. Ecology 1991, 72, 277-285. [CrossRef]

16. Daley, R.J. Experimental characterization of lacustrine chlorophyll diagenesis. II. Bacterial, viral and herbivore grazing effects. Arch. Hydrobiol. 1973, 72, 409-439.

17. Leavitt, P.R. A review of factors that regulate carotenoid and chlorophyll deposition and fossil pigment abundance. J. Paleolimnol. 1993, 9, 109-127. [CrossRef]

18. Davidson, T.A.; Sayer, C.D.; Perrow, M.; Bramm, M.; Jeppesen, E. The simultaneous inference of zooplanktivorous fish and macrophyte density from sub-fossil cladoceran assemblages: A multivariate regression tree approach. Freshw. Biol. 2010, 55, 546-564. [CrossRef]

19. Davidson, T.A.; Sayer, C.D.; Perrow, M.R.; Bramm, M.; Jeppesen, E. Are the controls of species composition similar for contemporary and sub-fossil cladoceran assemblages? A study of 39 shallow lakes of contrasting trophic status. J. Paleolimnol. 2007, 38, 117-134. [CrossRef] 
20. Hann, B.J.; Leavitt, P.R.; Chang, P.S.S. Cladocera community response to experitmental eutrophication in Lake 227 as recorded in laminated sediments. Can. J. Fish. Aquat. Sci. 1994, 51, 2312-2321. [CrossRef]

21. Jeppesen, E.; Jensen, J.P.; Amsinck, S.; Landkildehus, F.; Lauridsen, T.; Mitchell, S. Reconstructing the historical change in Daphnia mean size and planktivorous fish abundance in lakes from the size of Daphnia ephippia in the sediment. J. Paleolimnol. 2002, 27, 133-143. [CrossRef]

22. Verschuren, D.; Marnell, L.F. Fossil zooplankton and the historical status of westslope cutthroat trout in a headwater lake of Glacier National Park, Montana. Trans. Am. Fish. Soc. 1997, 126, 21-34. [CrossRef]

23. Paggi, J.C. Revisión de las especies argentinas del género Bosmina Bird agrupadas en el subenero Neobosmina Lieder (Crustacea: Cladocera). Acta Zool. Lilloana 1979, 35, 137-162.

24. Iriondo, M. Quaternary lakes of Argentina. Palaeogeogr. Palaeoclimatol. Palaeoecol. 1989, 70, 81-88. [CrossRef]

25. Sanzano, V.; Grosman, F.; Colasurdo, P. Estudio limnológico de Laguna Blanca Chica (Olavarría, Provincia de Buenos Aires) durante un período de sequía. Biol. Acuát. 2014, 30, 189-202.

26. Piovano, E.L.; Ariztegui, D.; Damatto-Moreira, S. Recent environmental changes in Laguna Mar Chiquita (central Argentina): A sedimentary model for a highly variable saline lake. Sedimentology 2002, 49, 1371-1384. [CrossRef]

27. Guerra, L.; Piovano, E.L.; Córdoba, F.E.; Sylvestre, F.; Damatto, S. The hydrological and environmental evolution of shallow Lake Melincué, central Argentinean Pampas, during the last millennium. J. Hydrol. 2015, 529, 570-583. [CrossRef]

28. González Sagrario, M.A.; Musazzi, S.; Córdoba, F.E.; Mendiolar, M.; Lami, A. Inferring the occurrence of regime shifts in a shallow lake during the last 250 years based on multiple indicators. Ecol. Indic. 2019, submitted.

29. Lami, A.; Musazzi, S.; Marchetto, A.; Buchaca, T.; Kerna, M.; Jeppesen, E.; Guilizzoni, P. Sedimentary pigments in 308 alpine lakes and their relation to environmental gradients. Adv. Limnol. 2009, 62, 217-238.

30. Korhola, A.; Rautio, M. Cladocera and other branchiopod crustaceans. In Tracking Environmental Change Using Lake Sediments; Zoological Indicators; Smol, J.P., Birks, H.J.B., Last, W.M., Eds.; Kluwer Academic Publisher: Dordrecht, The Netherlands, 2001; Volume 4, pp. 5-41.

31. Kotov, A.A. Separation of Leydigia louisi Jenkin, 1934 from L. leydigi (Schoedler, 1863) (Chydoridae, Anomopoda, Cladocera). Hydrobiologia 2003, 490, 147-168. [CrossRef]

32. Smirnov, N.N.; Kotov, A.A.; Coronel, J.S. Partial revision of the aduncus-like species of Pleuroxus Baird, 1843 (Chydoridae, Cladocera) from the southern hemisphere with comments on subgeneric differentiation within the genus. J. Nat. Hist. 2006, 40, 1617-1639. [CrossRef]

33. Szeroczyńska, K.; Sarmaja-Korjonen, K. Atlas of Subfossil Cladocera from Central and Northern Europe; Friends of the lower Vistula Society: Świecie, Poland, 2007; p. 84.

34. Wood, S.N. Generalized Additive Models: An Introduction with R, 2nd ed.; Chapman and Hall/CRC: Boca Raton FL, USA, 2017.

35. Simpson, G.L. Modelling palaeoecological time series using generalised additive models. Front. Ecol. Evol. 2018, 6, 149. [CrossRef]

36. Oksanen, J.; Blanchet, F.G.; Kindt, R.; Legendre, P.; Minchin, P.R.; O’Hara, R.B.; Simpson, G.L.; Solymos, P.; Stevens, M.H.H.; Wagner, H. Vegan: Community Ecology Package. R package version 2.2-1. 2015. Available online: http://cran.r-project.org (accessed on 15 November 2018).

37. Borcard, D.; Gillet, F.; Legendre, P. Numerical Ecology with R, 1st ed.; Springer: New York, NY, USA, 2011; p. 319.

38. R Core Team. R: A language and environment for statistical computing; R Foundation for Statistical Computing: Vienna, Austria, 2017; Available online: https://www.R-project.org/ (accessed on 15 November 2018).

39. Córdoba, F.E.; Piovano, E.L.; Guerra, L.; Mulsow, S.; Sylvestre, F.; Zárate, M. Independent time markers validate ${ }^{210} \mathrm{~Pb}$ chronologies for two shallow Argentine lakes in Southern Pampas. Quatern. Int. 2017, 438, 175-186. [CrossRef]

40. González Sagrario, M.A.; Balseiro, E.; Ituarte, R.; Spivak, E. Macrophytes as refuge or risky area for zooplankton: A balance set by littoral predacious macroinvertebrates. Freshw. Biol. 2009, 54, 1042-1053. [CrossRef]

41. Perga, M.-E.; Desmet, M.; Enters, D.; Reyss, J.-L. A century of bottom-up- and top-down driven changes on a lake planktonic food web: A paleoecological and paleoisotopic study of Lake Annecy, France. Limnol. Oceanogr. 2010, 55, 803-816. 
42. Amsinck, S.L.; Jeppesen, E.; Landkildehus, F. Inference of past changes in zooplankton community structure and planktivorous fish abundance from sedimentary subfossils-A study of a coastal lake subjected to major fish kill incidents during the past century. Arch. Hydrobiol. 2005, 162, 363-382. [CrossRef]

43. Korosi, J.B.; Kurek, J.; Smol, J.P. A review on utilizing Bosmina size structure archived in lake sediments to infer historic shifts in predation regimes. J. Plankton Res. 2013, 35, 444-460. [CrossRef]

44. Brahney, J.; Routledge, R.; Bos, D.G.; Pellatt, M.G. Changes to the productivity and trophic structure of a sockeye salmon Rearing Lake in British Columbia. N. Am. J. Fish. Manag. 2010, 30, 433-444. [CrossRef]

45. Davidson, T.A.; Sayer, C.D.; Langdon, P.G.; Burgess, A.; Jackson, M. Inferring past zooplanktivorous fish and macrophyte density in a shallow lake: Application of a new regression tree model. Freshw. Biol. 2010, 55, 584-599. [CrossRef]

46. Manca, M.; Torretta, B.; Comoli, P.; Amsinck, S.L.; Jeppesen, E. Major changes in trophic dynamics in large, deep sub-alpine Lake Maggiore from 1940s to 2002: A high resolution comparative palaeo-neolimnological study. Freshw. Biol. 2007, 52, 2256-2269. [CrossRef]

47. Acharya, K.; Kyle, M.; Elser, J.J. Effects of stoichiometric dietary mixing on Daphnia growth and reproduction. Oecologia 2003, 138, 333-340. [CrossRef]

48. Gliwicz, Z.M. Daphnia growth at different concentrations of blue-green filaments. Arch. Hydrobiol. 1990, 120, 51-65.

49. Davidson, T.A.; Bennion, H.; Jeppesen, E.; Clarke, G.H.; Sayer, C.D.; Morley, D.; Odgaard, B.V.; Rasmussen, P.; Rawcliffe, R.; Salgado, J.; et al. The role of cladocerans in tracking long-term change in shallow lake trophic status. Hydrobiologia 2011, 676, 299-315. [CrossRef]

(C) 2020 by the authors. Licensee MDPI, Basel, Switzerland. This article is an open access article distributed under the terms and conditions of the Creative Commons Attribution (CC BY) license (http://creativecommons.org/licenses/by/4.0/). 